\title{
Gerald Roche*
}

\section{Introduction: the transformation of Tibet's language ecology in the twenty-first century}

DOI 10.1515/ijsl-2017-0001

Abstract: Tibet's linguistic diversity is undergoing drastic transformations in the twenty-first century. In this article, I begin my examination of this issue by outlining the extent of Tibet's linguistic diversity, including not only its numerous Tibetic languages, but also its non-Tibetic minority languages. Using a "language ecology" approach, I examine the mechanisms that have produced and maintained this diversity, as well as the ways this diversity was spatially and socially patterned. I argue that these processes and patterns were largely maintained up until the twenty-first century, when the Chinese state's program to "Open the West" unleashed an ideologically driven modernization program on Tibet, radically altering its language ecology. I argue that the present trends emerging from this process are likely to continue throughout the twenty-first century, resulting in both language loss and the emergence of new languages, leaving the overall language ecology fundamentally altered by the beginning of the twenty-second century. It is hoped that this article will not only provide a useful framework for future discussions on linguistic diversity in Tibet, but will also focus attention on the challenges facing individual languages in Tibet today.

Keywords: Tibet, China, language ecology, language endangerment, modernization

\section{Introduction}

Tibet $^{1}$ is linguistically diverse. However, current developments in the region will see this diversity radically transformed by the start of the next century. Languages will be lost, new ones will emerge, and the patterns of interaction

1 For the purposes of this article, I define Tibet territorially as the total of Tibetan autonomous administrative units in China, but also include Tibetan populations outside of this area. When I speak of "the region", I refer to Tibet as thus defined, and not to the more restrictive Tibet Autonomous Region.

*Corresponding author: Gerald Roche, Asia Institute, Sidney Myer Asia Centre, University of Melbourne, Parkville, Victoria, Australia, E-mail: g.roche@unimelb.edu.au 
between the region's languages will be radically altered. This article, and the contributions to this special issue of the International Journal of the Sociology of Language, examine this issue of the contemporary transformation of Tibet's linguistic diversity. See Figure 1.

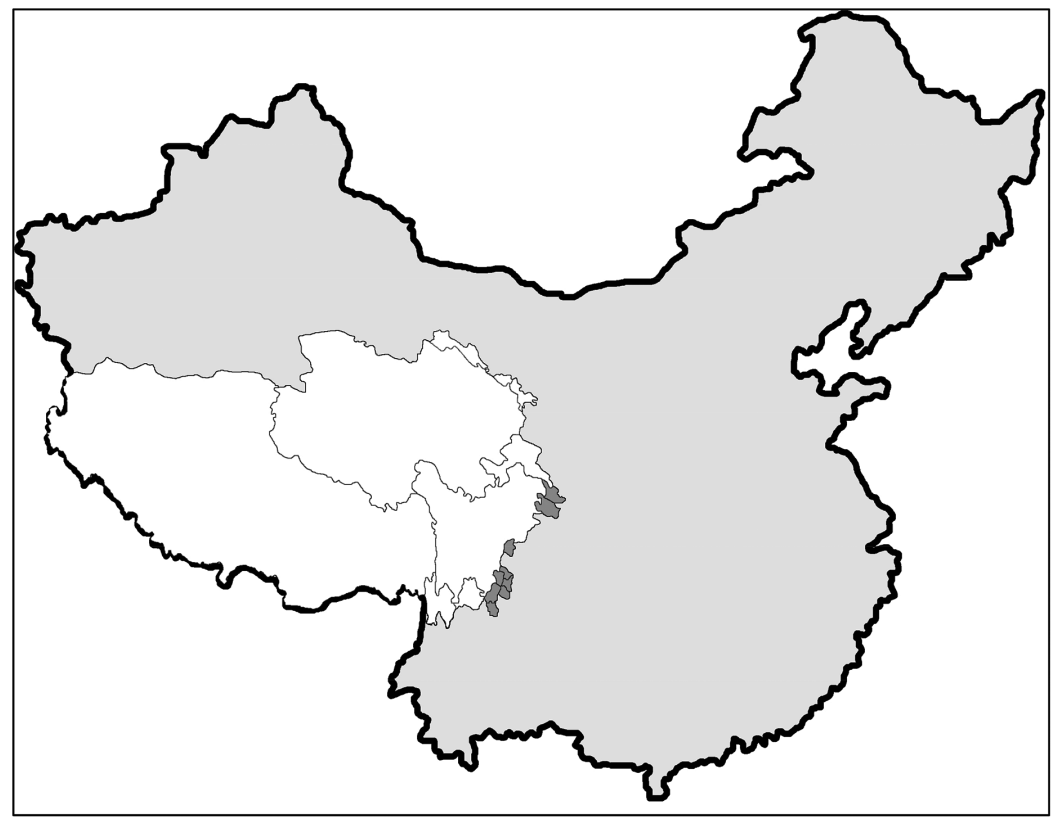

Figure 1: The Tibetan areas of the People's Republic of China.

Note: For the purpose of the literature survey conducted to determine the number of languages spoken in Tibet, all languages within the white area were counted. This area includes: all prefectures of the Tibet Autonomous Region and Qinghai Province; Sunnan Yugur Autonomous County, Tianzhu Tibetan Autonomous County, and Gannan Tibetan Autonomous Prefecture in Gansu Province; Aba and Ganzi Tibetan Autonomous Prefectures and Muli Tibetan Autonomous County in Sichuan Province; and Diqing Tibetan Autonomous Prefecture in Yunnan Province. In the dark gray areas on the eastern Tibetan Plateau, only languages spoken by Tibetans were counted. These areas include the following counties of Sichuan Province: Mianning, Ganluo, Yuexi, Xichang, Hanyuan, Shimian, Baoxing, and Pingwu and Wen County in Gansu.

To give some idea of Tibet's linguistic diversity, I begin by offering several estimates of the number of languages spoken in the region. It is important to note that counting languages can be problematic, insofar as it promotes a reductive definition of languages as "bounded, closed, and geographically fixed entities” (Moore et al. 2010: 1; see also; Dobrin et al. 2007). 
Such definitions also often produce descriptions of linguistic diversity that clash with local perceptions (Mühlhäusler 2002). Nonetheless, my aim in counting Tibet's languages is to highlight the extent, rather than the exact magnitude, of Tibet's linguistic diversity, primarily in opposition to the widelyheld assumptions that Tibetans speak a single language, which is the only one spoken in Tibet. I therefore provide multiple estimates for each count, rather than fixating on conclusive enumerations. ${ }^{2}$

The first aspect of Tibet's linguistic diversity that needs to be taken into consideration is the Tibetic languages - "a well-defined family of languages derived from Old Tibetan” (Tournadre 2013: 107, my emphasis). This family of languages is often called the Tibetan language. However, although Tibetan is a single written language (with classical and modern forms), there is no single spoken Tibetan language (Dawa Lodoe 2012). For instance, Germano (2003: 5), in a statement to Congressional-Executive Commission on China, argues that, "Tibetan can be thought of as a series of languages [that are] often mutually incomprehensible." Meanwhile, linguists in China recognize at least three major varieties of Tibetan - Amdo, Kham, and U-Tsang (Sum bho don grub tshe ring 2011), whereas the Ethnologue lists 11 "Bodish" languages spoken in China (Lewis et al. 2015). ${ }^{3}$ Another estimate comes from Nicolas Tournadre, who, in 2008, estimated that there were some 25 Tibetic languages, a figure that he raised to 50 in 2013. Kapstein (2006: 19) summarized the diversity among Tibetic forms and their relationship to the written language by comparing the situation to "Western Europe in the Middle Ages, when Latin remained the medium of literacy and learning while in each locality the inhabitants spoke Latin-derived dialects that were on the way to becoming the modern Romance languages." Therefore, while the actual number of Tibetic languages remains contested, there is scholarly consensus that there are multiple Tibetic languages rather than a single "Tibetan" language.

In addition to these Tibetic languages, Tibet is also home to numerous non-Tibetic minority languages. My use of the term "minority" implies, firstly,

2 It is also important to consider the parameters which frame the counts. Firstly, my count of language pertains to the territorial and demographic definition of Tibet as defined in Note 1. It also excludes sign languages used in Tibet (see Hofer, this volume), as well as specialized argots, such as secret languages used when hunting (Sun 1999) or harvesting salt (Koch 1997). I also exclude the region's writing systems from my count of languages. Furthermore, I do not impose any particular definition of what constitutes a language versus a dialect, but adopt the definitions used in the various sources referred to throughout the article.

3 The Bodish grouping used in the Ethnologue is somewhat broader than the Tibetic group proposed by Tournadre. 
demographic smallness. These languages have, on average, about 18,500 speakers, though the seven languages with the lowest number of speakers are spoken by a total of less than 7,000 people. However, "minority" also implies a political relationship between majority and minority - with minority languages lower in a prestige hierarchy, and lacking legitimation and institutionalization in the majority society (Williams 2005). ${ }^{4}$

It is difficult to say how many such minority languages are spoken in Tibet. The Chinese state's position, based on a strict correlation of language and ethnicity, is that there are 11 non-Tibetic languages spoken in the region. ${ }^{5}$ The eighteenth edition of Ethnologue, however, lists 38 such languages in Tibet. ${ }^{6}$ Meanwhile, my survey of contemporary English-language literature suggests that there are 52 minority languages spoken in Tibet. ${ }^{7}$ Which estimate is more realistic? The lowest estimate, based on ethnic identities and assuming a one-to-one correlation between ethnicity and language, is almost certainly too low, since as Sun (1992: 2) acknowledges, "of the 55 national minorities in China, 15 (27.7\%) use more than two languages". This suggests that a higher estimate, whether based on Ethnologue or other sources, better reflects the diversity of Tibet's minority languages.

I divide Tibet's minority languages into three categories on the basis of their distribution and official recognition. The first, I term "extraterritorial languages" (Williams 2005). These languages are recognized by the state and in addition to their presence in Tibet, have a "homeland" outside the region (either inside or outside China). Extraterritorial languages are therefore

4 My use of the term "minority" does not imply any connection to the Chinese term minzu, which is often translated as 'ethnic minority' or 'minority nationality'.

5 Mongolian, Monguor (Tu), Menba, Luoba, Salar, Qiang, Yi, Yugu, Drung, Naxi, and Pumi.

6 Bai (Lama), Baima, Boga'er Luoba, Bonan, Cuona Monba, Darang Deng, Drung, East Yugur, Ersu, Geman Deng, Guiqiong, Horpa, Jiarong, Kalmyk Oirat, Kangjia, Lavrung, Lisu, Muya, Namuyi, Narua, Naxi, Northern Pumi, Northern Qiang, Nuosu, Puroik, Queyu, Salar, Shixing, Southern Pumi, Southern Qiang, sTodsde, Thangmi, Tshangla, Tu, Western Yugur, Wutunhua, Yidu Luoba, and Zhaba.

7 This replaces my earlier count of 39 in Roche (2014). The languages identified in this survey are: Bai, Lama, Baima, Boga'er Luoba, Dakpa, Daohua, Darang Deng, Darmdo Minyak, Drung, Duoxu, Dza, Eastern Yugur, Ersu, Geman Deng, Geshitsa, Guiqiong, Japhug, Kangjia, Khroskyabs, Laze, Lisu, Lizu, Mangghuer, Manikacha, Mongghul, Na Bengni, Narua, Namuyi, Naxi, nDrapa, Ngandehua, Northern Pumi, Northern Rme, Nuosu, Nyarong Minyag, Oirat, Puroik, Queyu, Salar, sTodsde, Shimian Minyak, Situ rGyalrong, South-central rGyalrong, Southern Pumi, Southern Rme, sTau, Thangmi, Tshangla, Tsobdun, Western Yugur, Xumi, Yidu Luoba, and Zbu. For a full treatment of the complexities of conducting such a survey, as well as a range of estimates using different sources, see Roche and Suzuki (2017). 
minority languages in Tibet, but, elsewhere form a regional majority, or significant minority. Nuosu, Lisu, and Naxi are examples of such extraterritorial languages. A second group is the "enclaved languages" (Argenter 2008). ${ }^{8}$ These are spoken only within Tibet, and their speakers and their languages are recognized as being distinct from Tibetans. Examples of enclaved languages in Tibet include Salar and Mongghul. "Unrecognized languages" form a third group. These languages are only spoken by Tibetans in Tibet, but are not Tibetic languages; their speakers are therefore a "minority within a minority" (Todal 1999; see also Marti 2007). These include languages spoken by Deng Tibetans in the Tibet Autonomous Region, and Gyarong and Minyak Tibetans in Sichuan. Figure 2 shows the breakdown of Tibet's minority languages into these categories, using both the Ethnologue estimate and my own; the most significant difference lies in the increased number of non-recognized languages in my estimate.

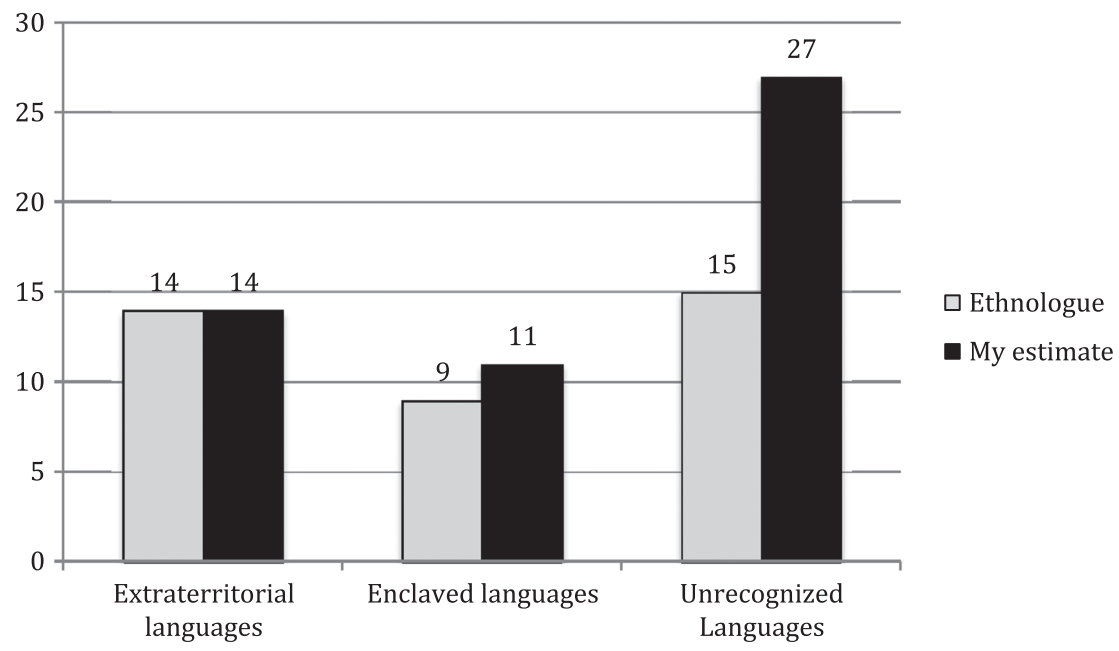

Figure 2: Tibet's minority languages: extraterritorial, enclave, and non-recognized languages.

In this essay, I examine Tibet's linguistic diversity using a "language ecology" approach. The term "language ecology" was first used by Voegelin et al. (1967) to refer to all the languages spoken within a specific region, and the complex interrelationships between them. And although such authors as Haugen (2001),

8 The term "language islands" (Rosenberg 2005) is also used in the literature. 
Wendel (2005), and Mufwene (2001) use "language ecology" and its variants (ecology of language(s), linguistic ecology, ecolinguistics) in somewhat divergent ways, most agree that a language ecology framework involves investigating a regional scale, focusing on all languages in an area rather than any single one, and exploring the interactions between those languages and their environments - social, physical, biological, and technological. "Ecology" is taken as a metaphor that draws attention to systemic diversity, dynamism, and complexity, and which encourages us to see the maintenance and endangerment of individual languages within broad, holistic contexts rather than in isolation (Mühlhäusler 1992; Denison 1982; Mackey 2001; Wendel and Heinrich 2012). Language ecology therefore provides a top-down, areal perspective on the same issues and questions that are asked from the grassroots level by scholars and activists seeking to maintain or revitalize individual languages.

A language ecology approach is useful in the case of Tibet for a number of reasons. Firstly, most linguistic studies in Tibet are primarily descriptive and provide only meager details of any single language's sociolinguistic context. Compiling this information, and combining it with insights from the historical and anthropological literature, however, provides a composite picture that cannot be gleaned from studies of any one language at present. Secondly, a language ecology approach provides a broad framework for future sociolinguistic studies of Tibet's languages, enabling scholars to investigate particular aspects of the ecology in the context of specific languages, and to accept, modify, or reject the many claims I make here. Finally, a language ecology framework has potential application in enabling us to consider how secure and sustainable environments may be created for all the languages of Tibet.

This article is divided into two parts, predicated upon a distinction between modern and pre-modern language ecologies. I use the start of the twenty-first century as a dividing line, since full-fledged modernization ${ }^{9}$ in Tibet did not

9 I define modernization as a "the passage from relative isolation and a relatively closed economy to union with the outside world through roads, railroads, and a money economy" (Weber 1976: x) as well as mass media, urbanization, and education. This process is typically state-driven, propelled by a "self-confidence about scientific and technical progress, the expansion of human production, the growing satisfaction of human needs, the mastery of nature (including human nature), and, above all, the rational design of social order”, (Scott 1998: 4) and results in conditions that are "no longer local ones but national" (Weber 1976: x). Another fundamental aspect of modernization is the "subordination of other forms of social organization to the demands of economic (primarily market) forms of organization”, (Fischer 2013: 32; see also; Wolf 2010). 
begin in earnest until the year 2000, under the Open the West agenda (Xibu da kaifa) (Goodman 2004; Barabantseva 2009; Potter 2010; Yeh 2013b; Fischer 2013; Harwood 2014). This modernizing project has brought roads, electricity, mass media, the cash economy, and compulsory education to Tibet, all of which connect populations the region to national, pan-Asian, and global cultural exchanges. Although I do not wish to reify a monolithic category of static, ahistorical "tradition" in contrast to a fundamentally dynamic modernity, I feel it is important to acknowledge that the advent of modernity and its capacity to collapse time and space represents a radical reconfiguration of the substantive nature of any language ecology. However, following Cabon and Molina's (2009) critique of Weber's (1976) portrayal of the modernization of rural France, I acknowledge that it is essential to consider the ways in which generic modernization processes are modified by specific, nationalist ideologies - a topic I take up later, in Section 3. Below, I begin by looking at the pre-modern language ecology of Tibet, and examine the dynamics and structures that gave rise to the pattern of linguistic diversity still found in Tibet at the end of the twentieth century.

\section{The way things were}

The building of empires and states, and the centralization this entails, are widely recognized as inimical to language diversity (Nichols 1992; Evans 2009; Wendel and Heinrich 2012). ${ }^{10}$ Much of Tibet has been subject to periods of local rule interspersed with rule from Lhasa or Beijing. In much of Amdo (northeast Tibet), for example, during the past 450 years, the influence of the Lhasa-based, Gelukpa Buddhist, Ganden Phodrang government increased from 1550, to become clearly domination from 1642 onwards, until rule from Beijing was instituted in 1725 , followed by a period of multipolar autonomy from 1850 to 1950. Rule from Lhasa saw the implementation of mass monasticism, and the enrollment of a large proportion of the male population in monasteries (Tuttle 2012). Linguistically, monasteries were not just places where people from diverse linguistic backgrounds mingled and learned a common written language, they also connected people to the centrifugal circulation of texts and the centripetal flows of people to centers of learning. Monasteries also united local populations into shared ritual cycles, regardless

10 This subtitle is taken from Weber's (1976) book Peasants into Frenchmen. 
of their language. Lhasa's rule was also successful in propagating a non-ethnic identity that allowed speakers of diverse languages to co-exist as part of a common religious ecumene. Qing rule, by contrast, was more divisive. Rather than integrating populations, it separated them. Communities were classified and territorially quarantined, curtailing mobility (Dai 2010), and, ultimately, leading to linguistic divergence (Roche 2015). Linguistic divergence also likely increased during periods of local autonomy, when monastic estates and local principalities assumed the status of "warring states" (Oidtman 2014). Even individual villages, described uncharitably as "little plague-spots of unowned and unruled independence” (Farrer 1926: 164), often had their own "self-defense organizations" (Wehrli 1992) that enabled them to maintain a robust autarky. Despite these oscillations in centralization and autonomy, however, since at least the mid sixteenth century, Tibet remained loosely integrated as an "empire of the word" (Ostler 2006) in which a common sacred literary tradition created shared understandings and desires and patterned human mobility, creating a structure whereby "the linguistic center [...] and the fringe areas [...] were effectively linked" (Ekvall 1964: 142).

At the same time that Tibet remained integrated through the written language, Tibetic languages have been influenced by those around them. Although the Tibetan language has been described as "inhospitable" to loan words (Ekvall 1964: 13), Laufer (1916), for example, notes “Indian”, Persian, Arabic, “Uigur”, "Turki”, Mongol, Manchu, Chinese, Portuguese, English, and Russian loanwords in Tibetan. This importation of words mirrors trade in other items - grains, domestic animals, and tents from Mesopotamia (Manderscheid 2001), coral from the Mediterranean, amber from the Baltic (Boulnois 2013), folklore templates from India (Schlepp 2002), and silver from the New World (Sperling 2010). Tibet's language ecology was thoroughly entangled in broader patterns of exchange.

Not only words and things, but also people, entered Tibet from afar. Longdistance migration helps explain the presence of many of Tibet's enclaved and extraterritorial minority languages. The Shirongolic languages of Amdo all originated in the immigration of Eastern (Khalkha) Mongols in the thirteenth century (Janhunen 2003). The thirteenth and fourteenth centuries saw an influx of Minyak populations to Kham "from the crushed Tangut state" (Sperling 2010: 299). The origins of the Turkic Salar language and several Sinitic varieties in Amdo can also be traced to the fourteenth century (Ma and Stuart 1996; Dede 2003). The next major migration occurred in the sixteenth and seventeenth centuries, bringing speakers of various forms of Western (Oirat) Mongol (Roche 2016). In addition to these "longer distance, unidirectional, en masse 
types of movement” (Huber 2012: 99), small numbers of Armenians (Richardson 1981), Gujaratis, Russians (Schram 2006), Kashmiris, and Shaanxi traders (Giersch 2010), among others, migrated to urban centers in Tibet without establishing permanent settlements.

Internal migration, within Tibet, was also important. We find, for example, radial migrations from Lhasa outwards during the imperial period. More significant, however, have been lateral migrations (Huber 2012; Roche 2015). Individuals, households, and sometimes entire communities, crossed mountains and rivers to make new homes elsewhere in Tibet. They were often fleeing conflict. This is what happened when farmers moved out of the agricultural vale of Rebgong, fleeing a clan feud, and became pastoralists in the grasslands of contemporary Xinghai County (Chos bstan rgyal 2014). Forced relocation after wars also occurred, for example, at the end of the Jinchuan Wars (Theobold 2013), or during Gonpo Namgyel's campaigns in the mid nineteenth century (Yudru Tsomu 2015). Apart from conflict, people also migrated to escape droughts and epidemics, and the destruction wrought by earthquakes ${ }^{11}$ and floods. They also set out in search of sbas yul, sacred 'hidden lands' where they could take refuge in times of calamity (Lim 2004; Sardar-Afkhami 1996).

Individual mobility also existed, especially for men. While women did travel, most significantly when they left their natal home to marry, ${ }^{12}$ mobility was much more pronounced for men. As lay pilgrims, monks, community leaders, bandits (Lama Jabb 2009), soldiers, and traders (van Spengen 2000), males had much greater scope for physical mobility than women. ${ }^{13}$ However, placing undue emphasis on these limited acts of mobility conceals the insularity that, until the twenty-first century, characterized the lived experience of most people in Tibet.

For herders, their lived world mostly consisted of seasonal pastures, stretching over a few tens of kilometers, and for farmers, it was their village and fields, limited to "the distance that could be traveled on foot in the morning so as to

11 For example, the 1786 Kangding-Luding Earthquake, the 1879 Gansu quake, the 1920 Haiyuan earthquake, or the 1950 Assam quake.

12 Except in communities that practiced matrilocal marriage, such as among the Zhaba (Feng 2010), and some speakers of Khroskyabs (G.yu lha 2012).

13 Although women did go on pilgrimage, there seems to have been an inverse relationship between the distance covered and the rate of female participation: men were much more likely than women to undertake long pilgrimage. So although Kapstein (1998:96) is correct in noting that there was "a sort of national pilgrimage network" that "helped maintain communications among even the most far-flung districts", this network, and the communication it allowed, was almost certainly gendered. 
return in the afternoon" (DuBois 2005: 24-25). Numerous obstacles restricted travel. Roads, bridges, ${ }^{14}$ traveller's inns, and wheeled transport were all rare. The wilderness between settlements was populated by bears, wolves, and, in the lowlands, leopards. Bandits also roamed the wilds, and beyond the wilds lay a patchwork of fiercely defended village territories (Wehrli 1992; Yudru Tsomu 2015). And in case people lacked incentives to stay home, there were also protective territorial and household deities that punished intruders.

People were also bound to home and hearth by ties of affect and obligation. One's homeland was not only the abode of one's beloved natal deity, but also the center of a mandala, a cosmogram of spatialized auspiciousness (Thurston 2012). These created the basis of a deep, and deeply localized, patriotism. People were also embedded in complex networks of reciprocity to their household, kin and mutual aid groups, and community, both their own village, and usually also a federation of villages. They were often also part of a monastic estate. These multiple belongings each entailed ritual and labor obligations that left little spare time for frivolous travel.

The factors that discouraged travel and tied people to home created a granular mosaic of self-contained, sequestered communities. Villages and valleys were bastions of difference, and speech forms could be highly divergent and localized at small scales, as the following proverbs demonstrate:

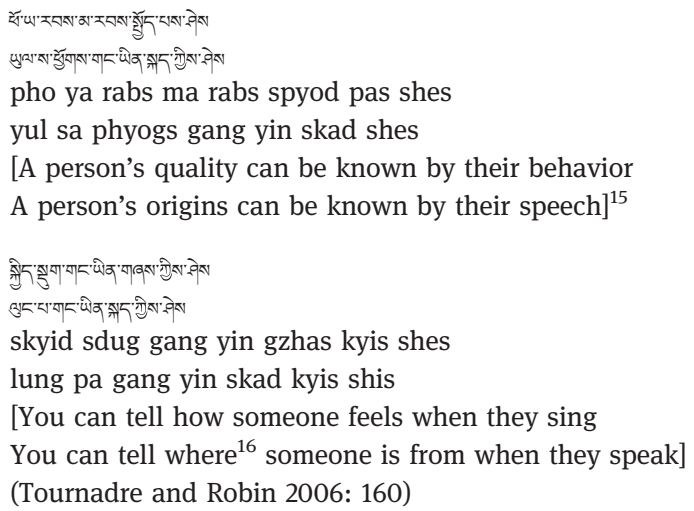

Language was therefore primarily a marker of local, rather than ethnic identities. And, localities could be quite small. It was not uncommon for people

\footnotetext{
14 The work of Tangtong Gyelpo notwithstanding (Gerner 2007; Stearns 2007).

15 My translations.

16 Literally, which valley.
} 
living in neighboring villages to speak different languages across centuries, but this was due primarily to social insularity, not physical separation, as is often assumed.

Nonetheless, geography did play a role in Tibet's linguistic diversity. Rivers, and their capacity to connect populations, rather than mountains, and their capacity to divide, were most significant in this regard. For long distance travel, riverine valleys were "smooth" corridors for travel in rough terrain. ${ }^{17}$ Trade, pilgrimage, migration, and warfare flowed with rivers. Settlements clustered in the riverine valleys, which were thus archipelagos of populated islands snaking through a more sparsely inhabited landscape. These islands were home to a "uniquely Tibetan historical urbanism" (Rohlf 2013: 168), characterized by the combination of commercial and religious functions. These centers drew people from the surrounding mountains, binding valleys and their hinterlands into large geographic units. That this hydrographic patterning of populations also created linguistic patterns is made explicit in this Ladakhi proverb:

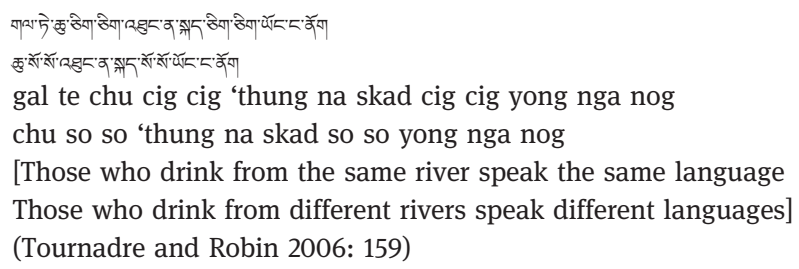

Following Skinner's division of China into hydrographic macro-regions (Skinner 1964, 1965a, 1965b), we can also divide Tibet following the drainage basins of its major rivers. Doing so reproduces, approximately, the traditionally recognized regions (and major Tibetan "dialects") of Amdo (northeast Tibet), Kham (east Tibet), and U-Tsang ("central” Tibet). ${ }^{18}$ Amdo is constituted by the drainage basin of the Yellow River; Kham by the Mekong, Yangtze, and Salween rivers, and U-Tsang by the Brahmaputra, Indus, and Sutlej rivers. The hydrological profile of each region also gives them broader geospatial orientations that have patterned their linguistic diversity. Amdo, defined by a river that flows to the north and east, is home to Sinitic, Mongolic, and Turkic minority

17 At a local scale, however, people often and easily crossed mountain ridges and ranges, and rivers sometimes served as barriers to movement, especially where bridges were lacking.

18 Although typically referred to as "central" Tibet, geographically speaking, U-Tsang is in the south of the area under discussion. 
languages. Kham, defined by rivers that flow to the east and southeast, contains a variety of Tibeto-Burman languages that are related to others found in southwest China. U-Tsang, meanwhile, is home to Tibetic forms closely related to those of South Asia below the Himalayas, and to numerous non-Tibetic languages spoken in northeast India. Furthermore, Amdo, Kham, and U-Tsang can each be divided into linguistically diverse downstream regions and relatively homogenous upstream regions. Upstream regions are typically beyond the reach of agriculture, and are thus home to mobile pastoral populations; besides the Mongolic populations of Amdo, all speakers of Tibet's minority languages live in downstream agricultural areas. See Figure 3.

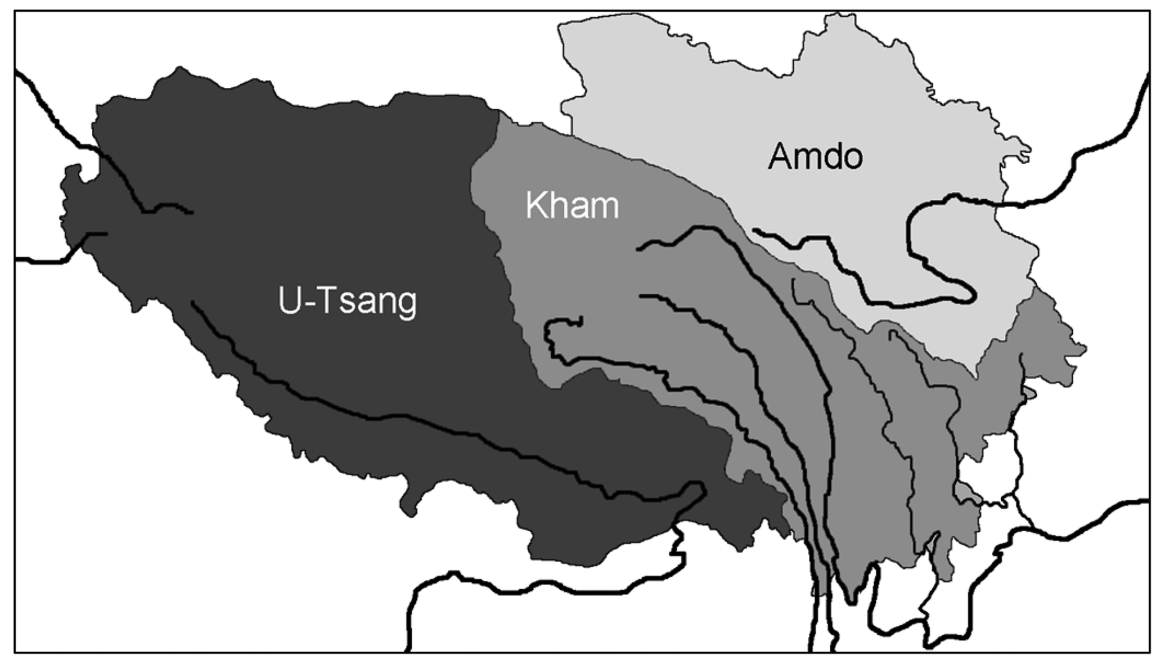

Figure 3: The division of Tibet into three major linguistic regions - U-Tsang, Kham, and Amdo - on the basin of river drainage basins.

The downstream portions of these regions each contained a linguistic area (Thomason 2001). Evidence for these regions is strongest in Amdo, less so in Kham, and merely suggestive in U-Tsang. In Amdo, a large body of research has described the exchange of both lexical items and grammatical features between the region's languages (Tas 1966; Nugteren and Roos 1996, 1998; Dede 2003; Slater 2003; Faehndrich 2007; Janhunen et al. 2007; Sandman 2012; Dwyer 2013). For Kham, Chirkova's (2012: 149) research in Muli has concluded that the region "[...] is an active convergence area, which includes languages that are 
genetically unrelated, but share a number of distinctive traits [...] because of contact-induced diffusion". Beyond this, it is unclear whether downstream Kham constitutes one linguistic area or several; only further research on the languages of Kham will clarify this. Meanwhile, research on areal linguistics in U-Tsang is even less advanced. Sun's (1999: 64) description of the "Dza" language of Zayu County in the TAR as, "a mixture of the [non-Tibetic] Geman [language] and Tibetan in both vocabulary and grammar" is suggestive of intense contact and convergence between languages in the area, but beyond this it is difficult to generalize further about the possibility of a linguistic area in downstream Kham. ${ }^{19}$

At the local level, dynamics of mobility and insularity and geographic patterns of diversity meant that most Tibetan communities were multilingual. To begin with, all Tibetan communities were characterized by some degree of diglossia (Ferguson 1959), though individual experience of diglossia varied - see below. A diglossic relationship existed between literary Tibetan and the many mutually unintelligible spoken Tibetic varieties, with classical literary Tibetan (and now modern literary Tibetan) functioning as the high variety and the spoken variety functioning as the low form (Bradley 2012a). ${ }^{20}$ Diglossia, however, was just the beginning of multilingual complexity. Figure 4 shows some of the different ways that a range of written and spoken languages could be present in a community.

\begin{tabular}{|c|c|c|c|c|c|}
\hline & $\begin{array}{l}\text { Oral } \\
\text { Tibetan }\end{array}$ & $\begin{array}{l}\text { Written } \\
\text { Tibetan }\end{array}$ & $\begin{array}{l}\text { Minority } \\
\text { language }\end{array}$ & \begin{tabular}{|l|}
$\begin{array}{l}\text { Written, } \\
\text { other }\end{array}$ \\
\end{tabular} & $\begin{array}{l}\begin{array}{l}\text { Oral, } \\
\text { other }\end{array} \\
\end{array}$ \\
\hline \multicolumn{6}{|l|}{ Diglossia } \\
\hline \multicolumn{6}{|l|}{$\begin{array}{l}\text { "Bilingualism" + } \\
\text { diglossia }\end{array}$} \\
\hline \multicolumn{6}{|l|}{ Triglossia } \\
\hline "Multilingualism" & & & & & \\
\hline
\end{tabular}

Figure 4: Patterns of multilingualism in Tibet.

19 Blackburn's (2008) folklore research, which identifies the downstream portion of U-Tsang as part of a cultural region he calls the "extended eastern Himalayas", is also suggestive in this regard.

20 A significant aspect of this diglossia was the widespread use of literary Tibetan in oral traditions, especially song and oratory, which were often not understood by the listeners (G.yu lha 2012; Bkra shis bzang po 2012). 
Patterns of multilingualism were based, in part, on the existence of a prestige hierarchy of languages and people in Tibet. Classical Tibetan, as a langua sacra, sat atop this hierarchy (Swank 2014; Chamberlain 2008). It not only served sacred functions, but was considered, in and of itself, both sacred and efficacious (Martin 1987; Diemberger 2012), giving speakers of the Tibetic languages, "if not a linguistic superiority complex, at least a reassuring sense of linguistic adequacy" (Ekvall 1964: 139). In contrast to the sacred efficaciousness of literary Tibetan, unwritten non-Tibetic languages were often described as unclear, ${ }^{21}$ and referred to as barbarian languages, ${ }^{22}$ backwards languages, ${ }^{23}$ or ghost languages (see Tunzhi this volume). ${ }^{24}$ Spoken Tibetic varieties sat somewhere between these two poles of sacred scripture and barbaric babble, though the variety spoken in Lhasa was often regarded as the highest among the spoken Tibetic forms, a contrast that French (2002: 257) describes as being between the "rude imperatives and staccato commands" of "rural dialectical variations" and the "more intonated and honorific Lhasa speech, which was a marker for place, education, and refinement". This prestige hierarchy among literary Tibetan, spoken Tibetic varieties, and minority languages meant that speakers of the last group were likely to be bilingual in some type of Tibetan, whereas Tibetan speakers rarely knew minority languages; bilingualism across two minority languages appears to have been even less common. This skewed pattern of multilingualism has been referred to as "inegalitarian bilingualism" by Hagège (2009).

Multilingualism in Tibet's pre-modern language ecology was also patterned by gender and geography. Males were more likely to have broader repertoires than women, due to their greater social and physical mobility, and were also more likely to have contact with the written word. Women were more likely to experience bilingualism temporally - to be born into a household speaking one language and married into a household where another was spoken. Finally, we may note that individuals in the downstream sections of hydrological regions encountered more diversity than those in the upstream regions. In general, farmers were more multilingual - and their languages more innovative (see Tribur this volume) - than pastoralists, and among farmers, speakers of minority languages were more likely to be more multilingual than speakers of prestigious Tibetic languages. Finally, monks and other monastics were more

\footnotetext{
21 केखाताख्य

22 为斯

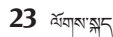

24 खेंग्रॉ
} 
likely to have wider linguistic repertoires than lay people. The most multilingual people in Tibet would therefore have been monks from farming regions whose first language was a minority language, whereas those with the least broad repertoire would have been pastoralist women who spoke a Tibetic language as their first language.

\section{Current predicaments}

A unique combination of nationalism and socialism based in Marxist-Leninist principles has, in the twenty-first century, propelled a modernization process that has radically altered Tibet's language ecology. The current predicament of Tibet's linguistic diversity is therefore not simply an outcome of the "inevitable historical tide" of modernization (State Council Information Office of the People's Republic of China 2015), nor can it be explained solely by the ideologies, policies, and practices of the Chinese state: the two exist synergistically.

Probably the most significant aspect of Tibet's contemporary language ecology is the ubiquity of a monoglot nationalist ideology representing Tibetans as a single people with a single language. ${ }^{25}$ Such nationalist ideologies emanate from diverse and sometimes surprising sources. In the twenty-first century, probably the most influential advocate for Tibetan nationalism has been the contemporary Chinese state.

The roots of the Chinese state's promotion of Tibetan nationalism can be traced to its project to classify its population into 56 "nationalities" in the 1950s. Rather than aiming to reflect China's linguistic and cultural diversity, this project was intended to reductively rationalize it (Mullaney 2011). Classification was the first step in a process that Hirsch calls "double assimilation" (Hirsch 2000, 2005) - "the assimilation of diverse peoples into nationality categories and the assimilation of nationally categorized groups" into mainstream society (Hirsch 2000: 213). Thus, the freedom that China's present constitution guarantees for the use and development of minority languages is, in fact, an assimilationist program for the 241 languages $^{26}$ in

25 Often, but not always, such claims are also linked to territorial claims of a linguistically and culturally homogenous Tibetan territory. Nonetheless, my usage of "nation" and "nationalism" must be distinguished from implications associated with the "nation-state".

26 Lewis et al. (2015) identify 297 languages of China. Since China recognizes 56 monoglot nationalities, the remaining 241 languages are subject to assimilatory pressures to fit into these categories. 
the country that are not associated with an official nationality. So, for example, although I estimate that people officially identified as Tibetans speak nearly 30 non-Tibetic languages (in addition to various Tibetic forms) they receive official recognition and support for only one language: Tibetan. This language is promoted by the Chinese state through a number of mechanisms: language standardization, corpus planning, print publishing, broadcasting, training and support of art and literary workers, new technological aids for the Tibetan language, such as fonts and software, and a Tibetanized regional education system (Nangsal Tenzin Norbu 2012; Lobsang 2012; Zhou 2007; Tournadre 2015). And since such support is offered to Tibetans as a monoglot nationality on a territorial basis under the framework of the regional ethnic autonomy law (Sayül Trowo Gyeltsen 2012), this means that both Tibet's unrecognized languages and extraterritorial languages are effectively subject to an assimilationist program. Only Tibet's enclaved minority languages, which have both official state recognition and a territorial base, are spared this state-led Tibetan assimilation program.

At the same time, however, Tibetans are subject to strong assimilatory pressures from the state, in accordance with the process of double assimilation. Firstly, we may note that the seemingly robust constitutional freedoms regarding language are actually provisioned in laws with much weaker wording, so that the use and developments of officially recognized languages is "desirable rather than mandatory" (de Varennes 2012: 19). The implementation of these laws is further impeded by a constitutional article (Article 51) prioritizing state interests over those of citizens (Tuttle 2008), and the curtailing of civil society's capacity to campaign for language rights. There is therefore a large gap between the strong constitutional freedoms and their provision (Zhou 2004). Meanwhile, the national language, Putonghua, is vigorously promoted (Saillard 2004; Tsung 2009), with its primacy enshrined in a 2001 Language Law (Rohsenow 2007). Putonghua now dominates print, broadcast, and online media, the linguistic landscape, education at all levels, all government organs and functions, and commerce (Tournadre 2003). Its ubiquity across all domains ensures its place as the language of social mobility in China, and also confers prestige on the language, which is in turn consolidated by discourses that associate Putonghua with progress, civilization, and human quality while denigrating minority and regional languages as backward, unscientific, and parochial (Bilik 2013). Lexical borrowing from Putonghua and code-switching between Tibetan and Putonghua have thus emerged as prominent anxieties among Tibetans in the twenty-first century (Kalsang Yeshe 2008).

The Chinese state, however, is not the only agent capable of projecting its ideological program onto the Tibetan population. Somewhat ironically, actors 
outside of China typically reproduce the monoglot ideology of the Chinese state's Tibetan nationalist project, even when they see themselves as directly opposed to the Chinese state and its goals. So, although these organizations have a wide range of often-contradictory goals, including various positions along the spectrum from autonomy to independence, they are all united in asserting the linguistic homogeneity of the Tibetan people. Organizations involved in supporting Tibetan monoglot nationalism include: the Central Tibetan Administration, ${ }^{27}$ the US government, the Unrepresented Nations and Peoples Organization, the Parliament of the European Union, ${ }^{28}$ the many national Tibet committees and "free Tibet" organizations, as well as a host of small NGOs working on aid, development, or cultural and linguistic preservation for Tibetans. All of these organizations adopt ideologies that reproduce the Chinese state's assimilatory program for Tibet's unrecognized languages. And when, in addition to a monoglot ideology, they also promote the idea of an ethnically homogenous Tibetan territory, they also deny recognition to the region's extraterritorial and enclaved languages.

Further adding to the complexity of the ideological landscape is a Tibetan “ethnic awakening" (Warner 2013), led by Buddhist elites and lay public intellectuals (Thurston 2015). Based on ideologies of loyalty (Thurston 2015), purity (High Peaks Pure Earth 2014a), unity (High Peaks Pure Earth 2014b), and ethnic essentialism (Gayley 2011), ${ }^{29}$ a number of loosely related initiatives have worked to both resist Chinese statist assimilation, while also advocating a homogenous Tibetan people. These initiatives have included: attempts to unify the timing of New Year celebrations throughout Tibet (High Peaks Pure Earth 2012); the promulgation and enforcement of a Tibetan legal code, known as the ten virtues (Buffetrille 2014); the regulation of dress as an outward sign of Tibetan identity (Yeh 2013a); a widespread "anti-slaughter" movement advocating vegetarianism for Tibetans (Gaerrang 2012; Barstow 2013); and corpus planning and grassroots language activism, including protests and the formation of communal language associations that monitor language use (Robin 2014; de Varennes 2012). Propelled by the moral force of Buddhism, coupled with state legitimacy and (sometimes) foreign funding, this Tibetan "ethnic awakening" has created an ideological environment that, at worst, portrays speakers of Tibet's minority

27 Also known as the Tibetan government in exile.

28 Through its Intergroup on Tibet, dissolved in 2014.

29 Gayley discusses the use of the term srog 'life force' in contemporary Tibetan discourses of culture, language, and ethnicity. I translate srog, and its related forms - tshe srog, bla srog - as 'essence'. 
languages as ethnic traitors or aliens, or at best as aberrant, problematic individuals. Speakers of Tibet's unrecognized languages are thus subject to a condition which Tenzin Jinba (2013) calls "double marginality" - peripheral and deviant as minorities within both the Chinese state and Tibetan nation.

Thus, the ideological landscape in Tibet is complex in terms of its agents and their interests, and yet these actors are surprisingly united in their promotion of a linguistically homogenous Tibetan nation. The key ideological tension surrounding Tibet's linguistic diversity is therefore between two nationalisms Tibetan and Chinese - and their monoglot visions. ${ }^{30}$ The pursuit of these ideological visions are both mediated and enabled by the technological, economic, and demographic transformations unleashed by the Open the West agenda in the twenty-first century, to which I turn my attention in the following paragraphs, beginning with an examination of transport infrastructure.

Travel in Tibet was slow and difficult until the end of the 20th century. For example, prior to 1949, it took "anywhere from several days to a week or more" to travel the 180 kilometers from Rebgong to Xining (Weiner 2012: 165). By 1990 this trip took approximately nine hours (Stevenson 2005), which shrank to five hours in 2005, and two in 2014. This change is indicative of the transformation of mobility and the compression of time and space in Tibet that has particularly taken in the twenty-first century. Dirt roads have been upgraded to gravel, then single lane asphalt roads, and multi-lane highways, and now a road network that initially linked provincial centers has branched to progressively smaller administrative levels, until, in Qinghai at least, every village is connected by a paved road. Tunnels have been bored through mountains, and bridges built across rivers and canyons, smoothing and collapsing the rough terrain. Meanwhile, pedestrian and horseback travel have declined as access to motorized transport has increased: from widespread use of an expanding network of local and long-distance public buses, to ownership and use of motorcycles (Iselin 2014), and now private cars. These developments in road transport have been mirrored by those in rail and air. Railways arrived in Tibet with a line to Xining in 1959, and have now been extended to Golmud (1984), Lhasa (2006), and Shigatse (2014). And while the first civilian airport in Tibet was built in 1965, the region is now home to fifteen airports, ${ }^{31}$ two of which are international. ${ }^{32}$

30 The reaction of speakers of Tibet's minority languages to this predicament remains a topic for further research.

31 Lhasa, Ngari, Nyingchi, Qamdo, Shigatse, Xining, Yushu, Golmud, Delingha, Deqen/ Shangri-La, Jiuzhai Huanglong, Daocheng, Kangding, Huangyuan, and Xiahe.

32 Xining and Lhasa. 
Not only have these developments put an end to the insularity of communities in Tibet, but they are also undermining hydrology's impact on broad regional patterns of diversity.

Integration into local, national, and global economic markets has also drastically impacted Tibet in the twenty-first century. This integration began following China's Reform and Opening program (initiated in 1978), which reduced state controls on labor and markets, and integrated the Chinese economy into the world system. For Tibetans, this program had little significant impact until the mid-1990s, and then crossed a critical threshold of momentum after the opening of the west (Fischer 2013). These market reforms have been accompanied by the rationalization and commercialization of subsistence activities (Weiner 2012; Schmitt 2014), leading to a labor surplus, ${ }^{33}$ which intensifies participation in income-generating activities, including entrepreneurship (Childs et al. 2011), migrant labor (Goldstein et al. 2008), and the lucrative trades in caterpillar fungus (Winkler 2008) and matsutake mushrooms (Yeh 2000) as well as increased participation in exploitative economic activities, such as pyramid schemes (Gonier and Rgyal yum sgrol ma 2012). Linguistically, one of the results of this increased market participation has been exposure to what has been called the "lunch pail threat" - the exposure of minority-language speakers to dominant languages in work settings (Keiser 2003). Understanding the impact of the "lunch pail threat" in Tibet will require ethnographic studies of linguistic practices at migrant labor sites. A holistic understanding of the broader linguistic outcomes of economic reform must also take into consideration that the same economic forces that created opportunities for Tibetan labor migration have also created opportunities for immigration into Tibet by people from elsewhere in China, both Han Chinese and other minorities (Roche 2011; Yeh 2013b).

Education in Tibet, like participation in the labor market, also often entails migration, as higher levels of schooling increasingly require movement to higher administrative levels (Wright 2014), sometimes even out of Tibetan administrative regions (Zhu 2007). Children therefore now typically spend more time in boarding schools than in their communities, and so teachers and other students replace the family and community as primary language socializers. Education thus drastically increases students' contact with dominant languages, while also eroding the communal insularity that once contributed to Tibet's

33 Fischer (2013: 33) notes that in the Tibet Autonomous Region, "the share of the local labor force considered as employed in the primary sector dropped from 74 percent in 2000[...] to 53 percent in 2000". 
linguistic diversity. This effect has increased markedly since the opening of the West, and the implementation of the nine-year compulsory education policy, completed in 2010, followed by the universalization of preschool education since 2011. Prior to this, participation in education was largely voluntary and enrolment rates were low, ${ }^{34}$ particularly for females (Bass 1998; Postiglione et al. 2005).

A core language policy of all Tibet's schools is the teaching of Putonghua. At best, this increases bilingualism without negatively impacting mother tongue competence, but, also, enforces inegalitarian bilingualism and realigns the language prestige hierarchy with Putonghua at the top, rather than Tibetan. At worst, schools are venues where subtractive bilingualism is practiced and language shift actively promoted through discriminatory attitudes and practices. Furthermore, educational policies deal only with officially recognized languages. Although Tibetan has a growing, yet still tenuous role in the education system (Yi 2007; Zenz 2010, 2014), Tibet's minority languages, particularly extraterritorial and unrecognized languages, are typically excluded from schools, and either a combination of Putonghua and Tibetan, ${ }^{35}$ or only Putonghua, are used. Despite these assimilatory policies, it is important to acknowledge that the impacts of educational practices on language shift in Tibet are poorly understood. Education in Tibet is typically teacher- and exam-focused - hardly an ideal context for language acquisition (Odlin 2003). The role of schools as venues for language shift therefore requires critical examination.

At the start of the twentieth century, Tibet's largest cities were Xining $(50,000$ people) and Lhasa $(30,000)$. Since then, not only have the populations of both cities increased drastically (to 2.2 million and 280,000 respectively), but the number of cities in Tibet has also shot up. The first step in Tibet's urbanization was "administrative urbanization" (Li 2007; Yeh and Henderson 2008) - the creation of a nested hierarchy of administrative divisions in which every unit above the village level has an urban core that serves administrative and commercial functions. Administrative urbanization continues today with the amalgamation and upgrading of rural units to consecutively larger,

34 For example, Postiglione et al. (2014) state that enrollment rates in the Tibet Autonomous Region rose from $50 \%$ in 1989, to $85 \%$ in 2000, and $98.5 \%$ in 2008.

35 For example, Ma (2014) states that for the Monpa, Lopa, Sarpa, and Deng people in the Tibet Autonomous Region, both Tibetan and Putonghua are used in schooling. Meanwhile, Jiang (2015) claims that only Chinese is used for schooling of Guiqiong speakers. 
denser urban units. ${ }^{36}$ Urbanization is also achieved through top-down resettlement programs, which have intensified since 2006, and the drive to create a "new socialist countryside" - "a rational, orderly, densely populated, and hygienic rural existence” (Robin 2009: 56; see also; Yeh 2013b). Meanwhile, "bottom-up" migration has also contributed to urbanization in Tibet. In some cases, this involves rural residents moving temporarily to urban areas to escape harsh winters (Yeh and Henderson 2008). Increasingly, however, rising incomes and growing flexibility in residential registration have seen permanent relocation to urban centers, sometimes in enclaves, though most often not. Urbanization is intensifying contact between diverse populations, breaking down traditional social forms, and creating new environments where Putonghua dominates as a lingua franca. Meanwhile, the flipside of urbanization - rural abandonment - is effectively eviscerating rural communities and restructuring pre-modern regions.

The development and spread of mass media has also been a significant aspect of modernization in Tibet. The development of infrastructure for electricity, which expanded significantly under the Open the West strategy (Zhang 2010; Yang 2005), has been crucial in this regards. Battery-powered radios and cassette players, communal megaphones, and travelling film projectors were important media prior to the opening of the West, but had only limited and intermittent reach. Television, VCD (video compact disc) and DVD players, as well as cellphones, the Internet, and social media become dominant, with near universal access, in the twenty-first century. Despite this change, radio, in Tibetan, remains an influential media, partly because it allows access to news and views from outside China (Bienier 2002).

Television overwhelmingly promotes Putonghua. Whilst dozens of stations in Tibet broadcast in Putonghua, only three regional stations, and a handful of local ones, broadcast in Tibetan, ${ }^{37}$ usually in non-vernacular, semi-standardized forms based on modern literary Tibetan, but using local pronunciation (Green 2012). Minority languages, particularly the unrecognized languages, have almost no presence on television. VCDs and DVDs, frequently used for popular music videos (Morcom 2006, 2007, 2008; Stirr 2008; Yangdon Dhondup 2008; Tsering Drolma and Wilson 2009; Warner 2013), are dominated by

36 Recent examples of this include the upgrading of Kangding, Ping'an, Yushu, and Nyingchi to cities.

37 The three regional TV stations are TAR TV Station, Qinghai Tibetan TV Station, and Khampa TV Station. Local TV stations broadcast either at the prefectural level (e. g., Malo TV Station) or the county level (e. g., Gansu Huari TV Station). 
Tibetan, usually non-vernacular "media" varieties (Lama Jabb 2011), whilst minority languages are again conspicuously absent. The vigorous but tightly controlled industry in the Tibetan printed word - books, magazines, and newspapers - also excludes Tibet's minority languages, and is dwarfed by the huge Chinese publishing industry (Maconi 2008). The only media where Tibet's minority languages have a presence is social media, particularly in the messaging service Weixin, which allows users to send voice messages. Other online and social media services that rely on the written word - including blogs, microblogs, and online news - are, like television and print publishing, overwhelmingly dominated by Chinese and exclude Tibet's minority languages, whilst providing a growing space for written Tibetan (Rigthub 2012).

Tibet's language ecology, then, has been completely transformed in the twenty-first century. The human mobility that was once the primary mediator of language contact has been intensified through urbanization, labor migration, and developments in transport infrastructure, while education and mass media have emerged as key technologies for mediating contact. Meanwhile, spatial patterns of diversity are being replaced by patterns based on ethnic categories. Proximity, contact, and convergence have been decoupled, and identity is emerging as the core structuring principle in Tibet's language ecology. Finally, the prestige hierarchy of Tibet's languages is being reconfigured, with Putonghua at the top, followed by Tibetan, then the region's minority languages: enclaved languages, extraterritorial languages, and finally the unrecognized languages at the bottom of the regional prestige hierarchy.

\section{Conclusion: future prospects for Tibet's linguistic diversity}

Given the transformation of Tibet's language ecology described above, what does the future hold for the region's linguistic diversity? In the years ahead, the modernization process in Tibet is likely to continue and intensify. Planned developments to transport infrastructure give some idea of the trajectory of regional modernization in the near future. Four new airports are scheduled for the region by $2020,{ }^{38}$ and plans exist to extend the railway network across the plateau and connect it to adjacent regions, with new lines including: Lhasa to Chengdu, Golmud to Dunhuang, Golmud to Korla, and Xining to Urumqi

38 Nakchu, Golog, Haixi, and Qilian. 
via Dunhuang. Lines from Beijing to Xining and Chengdu are presently being upgraded to high-speed rail. This rail network will eventually integrate into the planned "Belt and Road Initiative", a combined land and sea transport corridor and economic cooperation zone placing China at the center of a network extending through the Pacific, South and Southeast Asia, Central Asia, Russia, Baltic Europe, and the Mediterranean (Wildau 2015; Xinhua 2015). These changes in transport infrastructure will likely be matched by a growing market economy, expanding urbanization, continuing participation in an increasingly centralized educational system, and diversification and deepening penetration of media. Tibet will be increasingly integrated into the Chinese nation and will increasingly participate in global exchanges of ideas and things.

Ideologically, China's ethnic minority policies are unlikely to change significantly (Leibold 2013; Elliott 2015). According to Leibold (2014), the Chinese Communist Party's Central Ethnic Work Conference in September 2014 largely focused on affirming "the 'correctness' of the [Chinese Communist Party's] ethnic theory and policies since 1949," suggesting that the process of double assimilation set in motion by the ethnic classification project is likely to continue. Meanwhile, a revision of international organizations' ubiquitous ideology of Tibetans as a monoglot people seems unlikely. What does seem likely, however, is that the ability of such institutions to exert influence inside China will diminish as the Xi administration continues its program of curtailing foreign influence in building the Chinese Dream. Crucial to developments in Tibet's language ecology will be the future of the Tibetan ethnic awakening, its ability to persist and adapt, and the attitude it takes towards linguistic diversity - whether it continues promoting monoglot nationalism and ethnic essentialism or begins exploring a more linguistically inclusive Tibetan identity.

Given these trends, the current situation of Tibet's language ecology is likely to provide a relatively clear window on the future. Ethnic identities predicated on unified linguistic practice are likely to strengthen (Mullaney 2011) and the mechanism of double assimilation will increase pressure on Tibet's linguistic minorities, particularly speakers of unrecognized languages, to shift language. Language loss will occur. The Duoxu language, with nine speakers (Chirkova 2014), is likely to be the first. Among Tibet's 38 minority languages listed in Ethnologue (Lewis et al. 2015), two thirds (25) are threatened, shifting, or moribund, reflecting the situation across China more broadly. The Atlas of the world's languages in danger (Moseley 2010) identifies $47 \%$ of China's languages as vulnerable, severely endangered, definitely endangered, or critically endangered. Meanwhile, Ethnologue (Lewis et al. 2015) lists $54 \%$ of China's languages as threatened, shifting, 
moribund, or nearly extinct. Bradley (2012b) has stated that "Most of China's minority languages are likely to continue to decline [and] the rapid assimilation of smaller and less remote groups will increase." China is therefore likely on the brink of a widespread loss of languages, a significant number of which will be from those spoken in Tibet.

Concluding his observations on the present status of the literary Tibetan language, Tournadre (2003: 7) suggested that it “[...] has become an endangered language, condemned to an irreversible decline, if not outright extinction within two generations, if the present linguistic policy is maintained". How this applies to the many Tibetic languages is unclear, but indications are that at least some varieties are endangered (Peters 2014; Suzuki and Sonam Wangmo this volume). Meanwhile, Tibet's extraterritorial, enclave, and non-recognized languages are likely to suffer different fates. The extraterritorial minority languages, typically spoken as small enclaved populations in Tibet, are likely to undergo local extinctions - Balogh (this volume) describes such a situation for the Oirat idiom spoken in Henan County. Although this will represent an impoverishment of Tibet's language ecology, these languages will live on elsewhere, outside the region. Meanwhile, the unrecognized languages, now lacking any form of legitimation or institutionalizatIon, are under intense assimilatory pressure, and many of these populations are likely to undergo language shift. Whether they shift to some form of Chinese or Tibetan will depend on several factors. Local demography and education are likely to play important roles in determining the direction of shift, but identity will likely be the decisive factor. All else being equal, populations that accept their designation as Tibetans, such as most of the speakers of Minyak and Gyarong languages, may be more likely to shift to Tibetan, whereas those that reject their classification as Tibetan, such as the Deng (Olson 1998) or Baima (Upton 2000), may be more likely to shift to Chinese. Finally, Tibet's enclaved languages are likely to persist, but in forms that will be increasingly alienated from the linguistic areas they were once imbedded in. Quarantined within ethnic boundaries, these languages will remain proximal to, but no longer in contact with, Tibetic languages, and instead of conversion with local languages, Tibet's enclaved languages will be increasingly influenced by Putonghua.

Although language loss will undoubtedly be a significant aspect of the transformation of Tibet's language ecology, generative processes will also occur. Standardization is a key process driving the emergence of new language forms in the region. Although top-down attempts to standardize the Tibetic languages have a long history (Prins 2002; Dawa 2012), education and media practice are driving this process from above, creating and promoting regional standardized Tibetic languages, combining literary and vernacular elements 
(Lama Jabb 2011). Meanwhile, urbanization is also bringing about standardization, resulting in the emergence of local standardized vernaculars, as described by Suzukui and Sonam Wangmo, as well as Konchuk Gelek in this volume. ${ }^{39}$ Hofer (forthcoming) also describes the emergence of a standardized Tibetan Sign Language in Lhasa (TAR), which might replace household and community sign varieties otherwise used in the area.

Regardless of which languages disappear from Tibet, and which new ones appear there, the region's language ecology will have been drastically transformed by the end of the twenty-first century. The form it takes will depend on the balance between language loss, creation, maintenance, and revitalization (Mühlhäusler 1996). However, it is likely to be less diverse than it is today - purged of extraterritorial languages, and moving, slowly, towards realizing the vision of monoglot ethnicities all united by a dominant common tongue.

Acknowledgements: This special issue is based on papers that were given at the workshop "Minority Languages of the Chinese Tibetosphere: Ancient Trends, Contemporary Developments, and Future Prospects", held on 3 and 4 November 2014, at the Hugo Valentin Centre of Uppsala University, and funded by a Research Initiation Grant from the Riksbankens Jubileumsfond (\#F14-1339:1). My introductory essay benefitted greatly from the feedback of two anonymous reviewers and my colleagues at the Hugo Valentin Centre. I also presented sections of this work at the Tibetan Studies Outreach program at SOAS, Oxford University, Le Centre de recherches linguistiques sur l'Asie orientale, Humboldt University (Berlin), and Jagiellonian University, and received much thoughtful feedback from the people who attended those talks. Special thanks go to Lara Maconi and Elena McKinlay for their comments on the draft paper. All remaining errors are my own.

\section{References}

Argenter, Joan A. 2008. L’Alguer (Alghero), a Catalan Linguistic enclave in Sardinia. 193/194. 205-217.

Balogh, Mátyás. 2017. Henan Oirat: A shrinking pool of unique linguistic features. International journal of the sociology of language.

Barabantseva, V Elena. 2009. Development as localization: Ethnic minorities in China's official discourse on the Western Development Project. Critical Asian Studies 41(2). 225-254.

39 Peters (2014) has also described Tibet's new urban environments as venues for language shift. 
Barstow, Geoff. 2013. Buddhism between abstinence and indulgence: Vegetarianism in the life and works of Jigmé Lingpa. Journal of Buddhist Ethics 20. 74-104.

Bass, Catriona. 1998. Education in Tibet: Policy and practice since 1950. London: Zed books Bienier, Hansjörg. 2002. Broadcasting to Tibet. Central Asian Survey 21(4). 417-422.

Bilik, Naran. 2013. Minority education and language ideology. In Gray Tuttle, Kunsang Gya, Karma Dare \& Jonathan Wilber (eds.), The third international conference on Tibetan language (volume 1): Proceedings of the panels on domains of use and linguistic interactions. New York: Trace Foundation, 115-188

Bkra shis bzang po. 2012. May all good things gather here: Life, religion, and marriage in a Mi nyag Tibetan village. Asian Highlands Perspectives 14. 1-369.

Blackburn, Stuart H. 2008. Himalayan tribal tales: Oral tradition and culture in the Apatani Valley. Leiden: Brill.

Boulnois, Luce. 2013. Gold, wool, and musk: Trade in Lhasa in the seventeenth sentury. In Gray Tuttle \& Kurtis Schaeffer (eds.), The Tibetan history reader, 457-476. New York: Columbia University Press.

Bradley, David. 2012a. Standards, writing, and speaking in Tibetan and other Tibeto-Burman languages. In Gunsang Gya, Andrea Snavely \& Tsering Shakya (eds.), Minority languages in today's global society: Volume 2, 52-71. New York: Trace Foundation.

Bradley, David. 2012b. Vitality of minority languages. Author's preprint proof from The Encyclopedia of Chinese Languages and Linguistics. https://www.academia.edu/1555914/ Vitality_of_languages_in_China.

Buffetrille, Katia. 2014. A Controversy on vegetarianism. Revue d'Etudes Tibétaines 31. 113-127. Cabo, Miguel \& Fernando Molina. 2009. The long and winding road of nationalization: Eugen Weber's Peasants into Frenchmen in modern European history (1976-2006). European History Quarterly 39(2). 264-286.

Chamberlain, Bradford Lynn. 2008. Script selection for Tibetan-related languages in multiscriptal environments. International Journal of the Sociology of Language 192. 117-131.

Childs, Geoff, Melvyn C. Goldstein \& Puchung Wangdui. 2011. An entrepreneurial transition? Development and economic mobility in rural Tibet. Himalaya, the Journal of the Association for Nepal and Himalayan Studies 30(1). 13.

Chirkova, Ekaterina. 2012. The Qiangic subgroup from an areal perspective: A case study of languages of Muli. Language and Linguistics 13(1). 133-170.

Chirkova, Ekaterina. 2014. The Duoxu language and the Ersu-Lizu-Duoxu relationship. Linguistics of the Tibeto-Burman Area 37(1). 104-146.

Chos bstan rgyal. 2014. Following the herds: Rhythms of pastoral life in Amdo Asian Highlands Perspectives 32, http://www.plateauculture.org/writing/following-herds-rhythms-tibetanpastoral-life-mdo.

Dai, Yincong. 2010. The Sichuan frontier and Tibet: Imperial strategy in the early Qing. Seattle: University of Washington Press.

Dawa Lodoe. 2012. Discourse on a common spoken Tibetan language. In Gunsang Gya, Andrea Snavely \& Tsering Shakya (eds.), Minority languages in today's global society: Volume 2, 52-71. New York: Trace Foundation.

de Varennes, Fernand. 2012. Language rights and Tibetans in China: A look at international law. In Kunsang Gya, Andrea Snavely \& Elliot Sperling (eds.), Minority languages in today's global society,.New York: Trace Foundation, 2012.

Dede, Keith. 2003. The Chinese language in Qinghai. Studia orientalia 95. 321-346.

Denison, Norman. 1982. A linguistic ecology for Europe? Folia linguistica 16(1-4). 5-16. 
Diemberger, Hildegard. 2012. Holy books as ritual objects and vessels of teachings in the 'era of the further spread of the doctrine' (bstan pa yang dar). In Katia Buffetrille (ed.), Revisiting rituals in a changing Tibetan world, 9-42. Leiden: Brill.

Dobrin, Lise M., Peter K. Austin \& David Nathan. 2007. Dying to be counted: The commodification of endangered languages in documentary linguistics. 2007. Proceedings of the conference on language documentation and linguistic theory. School of Oriental and African Studies.

DuBois, Thomas David. 2005. The sacred village: Social change and religious life in rural north China. Honolulu: University of Hawai'i Press.

Dwyer, Arienne. 2013. Tibetan as a dominant sprachbund language: Its interactions with neighboring languages. In Gray Tuttle, Kunsang Gya, Karma Dare \& Jonathan Wilber (eds.), The third international conference on Tibetan language (volume 1): Proceedings of the panels on domains of use and linguistic interaction, 259-302. New York: Trace Foundation.

Ekvall, Robert. 1964. Religious observances in Tibet: Patterns and function. Chicago: University of Chicago Press.

Elliott, Mark. 2015. The case of the missing indigene: Debate over a "second-generation" ethnic policy. China journal 73. 186-213.

Evans, Nicholas. 2009. Dying words: Endangered languages and what they have to tell us. Chichester: John Wiley \& Sons.

Faehndrich, Burgel RM. 2007. Sketch grammar of the Karlong variety of Mongghul, and dialectal survey of Mongghul. University of Hawai'l PhD thesis.

Farrer, Reginald. 1926. On the eaves of the world. London: E. Arnold.

Feng, Min (translated by Mtsho mo skyid and Gerald Roche). 2010. Matrilinieal marriage in Tibetan areas in western Sichuan province. Asian highlands perspectives 6. 251-280. http://www.plateauculture.org/writing/matrilineal-marriage-tibetan-areas-westernsichuan-province

Ferguson, Charles Albert. 1959. Diglossia. Word-Journal of the international linguistic association 15(2). 325-340.

Fischer, Andrew Martin. 2013. The disempowered development of Tibet in China: A study in the economics of marginalization. New York: Lexington Books.

G.yu lha. 2012. Warming your hands with moonlight: Lavrung Tibetan oral traditions and culture. Asian highlands perspectives 12. http://www. plateauculture.org/writing/warmingyour-hands-moonlight-lavrung-tibetan-oral-traditions-and-culture

Gaerrang (Kabzung). 2012. Alternative development on the Tibetan Plateau: The case of the slaughter renunciation movement. University of Colorado, Boulder Ph.D thesis.

Gayley, Holly. 2011. The ethics of cultural survival: A Buddhist vision of progress in Mkhan po ‘Jigs phun's Heart advice to Tibetans for the $21^{\text {st }}$ century. In Gray Tuttle (ed.), Mapping the modern in Tibet, 435-502. Halle: IITBS.

Germano, David. 2003. Statement presented to the round table on 'Teaching and learning Tibetan: The role of the Tibetan language in Tibet's future' for the Congressional Executive Commission on China. http://www.cecc.gov/events/roundtables/teaching-and-learningtibetan-the-role-of-the-tibetan-language-in-tibets-future

Gerner, Manfred. 2007. Chakzampa Thangtong Gyalpo: Architect, philosopher and iron chain bridge builder. Thimpu: Centre for Bhutan Studies.

Giersch, C. Patterson. 2010. Across Zomia with merchants, monks, and musk: Process geographies, trade networks and the Inner-East-Southeast Asian borderlands. Journal of Global History 5(2). 215-239 
Goldstein, Melvyn C., Geoff Childs \& Puchung Wangdui. 2008. "Going for Income” in village Tibet: A longitudinal analysis of change and adaptation, 1997-2007. Asian survey 48(4). 514-534.

Gonier and Rgyal yum sgrol ma. 2012. Pyramid schemes on the Tibetan Plateau. Asian highlands perspectives 21. 113-140, http://www. plateauculture.org/writing/pyramid-schemestibetan-plateau

Goodman, David. 2004. The campaign to 'Open Up the West': National, provincial-level, and local perspectives. China quarterly. 178. 317-334.

Green, Jeffrey. 2012. Amdo Tibetan media intelligibility. SIL electronic survey reports, http://www.sil.org/resources/publications/entry/48318

Hagège, Claude (translated by Jody Gladding). 2009. On the death and life of languages. New Haven: Yale University Press.

Harwood, Russell. 2014. China's new Socialist countryside: Modernity arrives in the Nu River Valley. Seattle: Washington University Press.

Haugen, Einar. 2001. The ecology of language. In Alwin Fill \& Peter Mühlhäusler (eds.), The ecolinguistics reader: Language, ecology, and environment, 57-66. London: Continuum.

High Peaks Pure Earth. 2012. The online debate continues: Do we need a common Losar? http://highpeakspureearth.com/2012/the-online-debate-continues-do-we-need-a-com mon-losar/

High Peaks Pure Earth. 2014a. 'On unity': The third chapter of 'The Restless Himalayas' by Dolma Kyap. http://highpeakspureearth.com/2014/on-unity-third-chapter-of-the-restlesshimalayas-by-dolma-kyab/

High Peaks Pure Earth. 2014b. http://highpeakspureearth.com/2014/an-urgent-call-for-theprotection-and-preservation-of-tibetan-language-by-khenpo-tsultrim-lodoe/

Hirsch, Francine. 2000. Toward an empire of nations: Border-making and the formation of soviet national identities. The Russian review 59(2). 201-226.

Hirsch, Francine. 2005. Empire of nations: Ethnographic knowledge and the making of the Soviet Union. New York: Cornell University Press.

Hofer, Teresia. 2017. Is Lhasa Tibetan Sign Language emerging, endangered, or both? International journal of the sociology of language.

Huber, Toni. 2012. Micro-migrations of hill peoples in northern Arunachal Pradesh: Rethinking methodologies and claims of origins in Tibet. In Toni Huber \& Stuart Blackburn (eds.), Origins and migrations in the extended eastern Himalayas, 83-106. Leiden: Brill.

Iselin, Lilian. 2014. Translocal practices on the Tibetan Plateau: Motorised mobility of pastoralists and spatial transformations. Nomadic peoples 18(1). 15-37.

Janhunen, Juha. 2003. Shirongol and Shirongolic. Studia etymologica Cracoviensia 8. 83-89.

Janhunen, Juha, Lionel Ha Mingzong \& Joseph Tshe dpag rnam Rgyal. 2007. On the language of the Shaowa Tuzu in the context of the ethnic taxonomy of Amdo Qinghai. Central Asiatic journal 51(2). 177-195.

Jiang, Li. 2015. A grammar of Guiqiong: A language of Sichuan. Leiden: Brill.

Lama Jabb. Banditry in traditional Amdo: The story of Yidak Kela. In Wim van Spengen \& Lama Jabb (eds.), Studies in the history of eastern Tibet. Halle: IITBS, 2009.

Lama Jabb. 2011. Singing the nation: Modern Tibetan music and national identity. Revue d’Etudes Tibétaines 21. 1-29. 
Kapstein, Matthew. 1998. A pilgrimage of rebirth reborn: The 1992 celebration of the Drigung Powa Chenmo. In Melvyn Goldstein \& Matthew Kapstein (eds.), Buddhism in contemporary Tibet: Religious revival and cultural identity, 95-119. Delhi: Motilal Banrsidass.

Kapstein, Matthew. 2006. The Tibetans. Oxford: Blackwell Publishing.

Keiser, Steve Hartman. 2003. Pennsylvania German and the 'lunch pail threat': Language shift and cultural maintenance in two Amish communities. In Brian Jospeh, Johanna DeStefano, Neil Jacobs \& Ilse Lehiste (eds.), When languages collide: Perspectives on language conflict, language competition, and language coexistence, 3-20. Columbus: The Ohio State University Press.

Koch, Ulrike. 1997. The saltman of Tibet. New York: Zeitgeist Video.

Konchok Gelek. 2017. Variation, contact, and change in language varieties in Yul shul (northern Khams). International journal of the sociology of language.

Laufer, Berthold. 1916. Loan-words in Tibetan. T'oung pao 17. 403-552.

Leibold, James. 2013. Ethnic policy in China: Is reform inevitable? Honolulu: East-West Center.

Leibold, James. 2014. A family divided: The CCP's Central Ethnic Work Conference. China brief 14(21). http://www.jamestown.org/programs/chinabrief/single/?tx_ttnews[tt_news] =43054\&tx_ttnews[backPid] $=25 \&$ cHash=69cddfb62b8fb63343a35cd4a16652e9\&\&_ga=1. 151815737.1080092196.1429617147\#.VTY9-xOUee5

Lewis, M. Paul, Gary F. Simons \& Charles D. Fennig (eds.). 2015. Ethnologue: Languages of the world, eighteenth edition. Dallas, Texas: SIL International. Online version: http://www.ethnologue.com

Li, Tao. 2007. A study of the Tibetan rural urbanization model. China report 43(1). 31-42.

Lim, Francis Khek Gee. 2004. Zombie slayers in a 'hidden valley'(sbas yul): Sacred geography and political organisation in the Nepal-Tibet borderland. European bulletin of Himalayan research 27. 37-66.

Lobsang, Monlam. 2012. The development and application of Monlam Tibetan font. In Gunsang Gya, Andrea Snavely \& Tsering Shakya (eds.), Minority languages in today's global society: Volume 2, 256-296. New York: Trace Foundation.

Ma, Jianzhong \& Kevin Stuart. 1996. Stone camels and clear springs: The Salar's Samarkand origins. Asian folklore studies 55(2). 287-298.

Ma, Rong. 2014. Bilingual education and language policy in Tibet. In James Leibold \& Chen Yangbin (eds.), Minority education in China: Balancing unity and diversity in an era of critical pluralism, 83-106. Hong Kong: Hong Kong University Press.

Mackey, William F. 2001. The ecology of language shift. In Alwin Fill \& Peter Mühlhäusler (eds.), The ecolinguistics reader: Language, ecology, and environment, 67-74. London: Continuum.

Maconi, Lara. 2008. One nation, two discourses: Tibetan new era literature and the language debate. In Lauren Hartley \& Patricia Schiaffini-Vedani (eds.), Modern Tibetan literature and social change, 173-201. Durham: Duke University Press.

Manderscheid, Angela. 2001. The black tent in its easternmost distribution: The case of the Tibetan Plateau. Mountain research and development 21(2). 154-160.

Marti, Roland. 2007. Lower Sorbian - Twice a minority language. International journal of the sociology of language 183. 31-51.

Martin, Dan. 1987. On the origin and significance of the prayer wheel according to two nineteenth-century Tibetan literary sources. The Journal of the Tibet Society 7. 3-29.

Moore, Robert E., Sari Pietikäinen \& Jan Blommaert. 2010. Counting the losses: Numbers as the language of language endangerment. Sociolinguistic Studies 4(1). 1-26. 
Morcom, Anna. 2006. History, traditions, identities and nationalism: Drawing and redrawing the musical cultural map of Tibet. PIATS 2006, http://s3.amazonaws.com/academia.edu. documents/30733624/Morcom_Histories_traditions_and_identities_PIATS_2011.pdf? AWSAccessKeyld $=$ AKIAJ56TQJRTWSMTNPEA\&Expires $=1430331715 \&$ Signature $=6$ V $\%$ 2FeAsZA8911JfEkx2dnmCkHGPU\%3D\&response-content-disposition=inline

Morcom, Anna. 2007. Modernity, power and the reconstruction of dance in post 1950s Tibet. Journal of the International Association of Tibetan Studies 3. 1-32.

Morcom, Anna. 2008. Getting heard in Tibet: Music, media and markets. Consumption, Markets and Culture 11(4). 259-285.

Moseley, Christopher (ed.). 2010. Atlas of the world's languages in danger, 3rd edn. Paris: UNESCO Publishing. Online version: http://www.unesco.org/culture/en/endangeredlan guages/atlas

Mufwene, Salikoko. 2001. The ecology of language evolution. Cambridge: Cambridge University Press.

Mühlhäusler, Peter. 1992. Preserving languages or language ecologies? A top-down approach to language survival. Oceanic Linguistics 31(2). 163-180.

Mühlhäusler, Peter. 1996. Linguistic ecology: Language change and linguistic imperialism in the Pacific region. London: Routledge.

Mühlhäusler, Peter. 2001. Why one cannot preserve languages (but can preserve language ecologies). In David Bradley \& Maya Bradley (eds.) Language Endangerment and Maintenance 34-39. London: Routledge.

Mullaney, Thomas. 2011. Coming to terms with the nation: Ethnic classification in modern China. Berkeley: University of California Press.

Nangsal Tenzin Norbu. 2012. Thoughts on the teaching of natural science in Tibetan. In Gunsang Gya, Andrea Snavely \& Elliot Sperling (eds) Minority languages in today's global society: Volume 1, 107-126. New York: Trace Foundation.

Nichols, Johanna. 1992. Linguistic diversity in space and time. Chicago: University of Chicago Press.

Nugteren, Hans \& Marti Roos. 1996. Common vocabulary of the western and eastern Yugur languages: The Turkic and Mongolic loanwords. Acta Orientalia 49(1). 25-91.

Nugteren, Hans \& Marti Roos. 1998. Common vocabulary of the western and eastern Yugur languages: The Tibetan loanwords. Studia etymologica Cracoviensia 3. 45-92.

Odlin, Terence. 2003. Language ecology and the Columbian exchange. In Brian Jospeh, Johanna DeStefano, Neil Jacobs \& Ilse Lehiste (eds.), When languages collide: Perspectives on language conflict, language competition, and language coexistence, 71-94. Columbus: The Ohio State University Press.

Oidtman, Max. 2014. Between patron and priest: Amdo Tibet under Qing rule, 1792-1911. Harvard University PhD dissertation

Olson, James Stuart. 1998. An ethnohistorical dictionary of China. Santa Barbara, CA: Greenwood Publishing Group.

Ostler, Nicholas. 2006. Empires of the word: A language history of the world. New York: HarperCollins.

Peters, Simon. 2014. Gyalthang Southern Khams Tibetan: A case study of language attitudes and shift in Shangri-la. Anthós 6(1). 111-136.

Postiglione, Gerard, Ben Jiao \& Sonam Gyatso. 2005. Education in rural Tibet: Development, problems and adaptations. China: An International Journal 3(1). 1-23. 
Postiglione, Gerard, Ben Jiao, Tsamla. 2014. Popularizing basic education in Tibet's nomadic regions. In James Leibold \& Chen Yangbin (eds.), Minority education in China: Balancing unity and diversity in an era of critical pluralism, 107-130. Hong Kong: Hong Kong University Press.

Potter, Pitman. 2010. Economy and development on the inner periphery. In Pitman Potter Law, policy, and practice on China's periphery, 116:141. London: Routledge.

Prins, Marielle. 2002. Towards a Tibetan common language: A mdo perspectives on attempts at language standardization. In Toni Huber (ed.), Amdo Tibetans in transition: Society and culture in the Post-Mao era, 27-52. Leiden: Brill.

Richardson, Hugh. 1981. Armenians in India and Tibet. Tibet Society Journal 1. 63-67.

Rigthub. 2012. The situation and consideration of Tibetan language in social media. In Gunsang Gya, Andrea Snavely \& Tsering Shakya (eds.), Minority Languages in Today's Global Society: Volume 2, 297-320. New York: Trace Foundation.

Robin, Françoise. 2009. The 'socialist new villages' in the Tibetan Autonomous Region: Reshaping the rural landscape and controlling its inhabitants. China Perspectives 3: 5564, http://chinaperspectives.revues.org/4845

Robin, Françoise. 2014. Streets, slogans and screens: New paradigms for the defense of the Tibetan language. In Trine Brox \& Ildikó Bellér-Hann (eds.), On the fringes of the harmonious society: Tibetans and Uyghurs in socialist China, 209-234. Copenhagen: NIAS Press.

Roche, Gerald. 2011. Nadun: Ritual and the dynamics of diversity in northwest China's Hehuang region. Australia: Griffith University PhD diss.

Roche, Gerald. 2014. The vitality of Tibet's minority languages in the twenty-first century: Preliminary remarks Multiethnica 35. 24-30.

Roche, Gerald. 2016. The Tibetanization of Henan: Ethnicity and assimilation on the SinoTibetan frontier. Asian Ethnicity 17(1). 128-149.

Roche, Gerald. 2015b. Nadun: Ritual and history on the northeast Tibetan plateau. In Mariko Namba Walter \& James P. Ito-Adler (eds.), The silk road: Interwoven history. Volume 1: Long-distance trade, culture, and society, 310-347. Cambridge, MA: Cambridge Institutes Press and the Association for Central Asian Civilizations and Silk Road Studies.

Rohlf, Gregory. 2013. A preliminary investigation of the urban morphology of towns on the Qinghai-Tibetan plateau. In Yongtao Du \& Jeff Kyong-McClain (eds.), Chinese history in geographical perspective, 159-177. New York: Lexington Books.

Rohsenow, John. 2007. Fifty years of script and written language reform in the PRC: The genesis of the language law of 2001. In Minglang Zhou and Hongkai Sun (eds.), Language policy in the People's Republic of China: Theory and practice since 1949, 21-44. Boston: Kluwer Academic Publishers.

Rosenberg, Peter. 2005. Dialect convergence in the German language islands (Sprachinseln). In Peter Auer, Frans Hinskens \& Paul Kerswill (eds.), Dialect change: Convergence and divergence in European languages, 221-235 Cambridge: Cambridge University Press.

Saillard, Claire. 2004. On the promotion of Putonghua in China. In Minglang Zhou \& Hongkai Sun (eds.), Language policy in the People's Republic of China: Theory and practice since 1949, 163-176. Boston: Kluwer Academic Publishers.

Sandman, Erika. 2012. Bonan grammatical features in Wutun. Mémoires de la Société FinnoOugrienne 264. 375-387

Sardar-Afkhami, Hamid. 1996. An account of Padma-bkod: A hidden land in southeastern Tibet. Kailash 18(3-4). 1-21. 
Sayül Trowo Gyeltsen. 2012. The realities of China's minority language laws: A comment on Tibetan language learning in relation to the 'ten rights'. In Gunsang Gya, Andrea Snavely \& Elliot Sperling (eds.), Minority languages in today's global society: Volume 1, 273-304. New York: Trace Foundation.

Schlepp, Wayne. 2002. Cinderella in Tibet. Asian folklore studies 61(1). 123-147.

Schmitt, Edwin A. 2014. The history and development of de-swiddening among the Ersu in Sichuan, China. Himalaya, the journal of the association for Nepal and Himalayan studies 34(2). 12.

Schram, Louis M.J. 2006 [1954, 1957, 1961] The Monguors of the Kansu-Tibetan frontier, Part I: Their origin, history and social organization; Part II: Their religious life; Part III: Records of the Monguor clans: History of the Monguors in Huanchung and the chronicles of the Lu family. Xining City: Plateau Publications.

Scott, James. 1998. Seeing like a state: How certain schemes to improve the human condition have failed. New Haven: Yale University Press.

Skinner, G. William. 1964. Marketing and social structure in rural China, part I. The Journal of Asian Studies 24(1). 3-43.

Skinner, G. William. 1965a. Marketing and social structure in rural China, part II. The Journal of Asian Studies 24(2). 195-228.

Skinner, G. William. 1965b. Marketing and social structure in rural China, part III. The Journal of Asian Studies 24(3). 363-399.

Slater, Keith. 2003. Mangghuer: A Mongolic language of China's Qinghai-Gansu sprachbund. London \& New York: Routledge.

Sperling, Elliot. 2010. Some preliminary remarks on the influx of New World silver into Tibet during China's 'silver century' (1550-1650). In Roberto Vitali (ed.), The earth ox papers. The Tibet journal. 34(3). 299-311.

State Council Information Office of the People's Republic of China. 2015. White paper: Tibet's path of development is driven by an irresistible historical tide. http://www.china.org.cn/ china/2015-04/15/content_35325433.htm

Stearns, Cyrus. 2007. King of the empty plain: The Tibetan iron-bridge builder, Tangtong Gyalpo. Boston: Snow Lion Publications

Stevenson, Mark. 2005. Many paths: Searching for old Tibet in new China. Melbourne: Lothian Books.

Stirr, Anna. 2008. Blue Lake: Tibetan popular music, place and fantasies of the nation. Robert Barnett \& Robert Schwartz (eds.), Tibetan modernities: Notes from the field on cultural and social change, 305-332. Leiden: Brill.

Sum bho don grub tshe ring. 2011. Bod skad kyi yul skad rnam shad [A discussion of Tibetan dialects]. Beijing: Krung go'i bod rig pa dpe skrun khang [China Tibetology Press].

Sun, Hongkai. 1992. On nationality and the recognition of Tibeto-Burman languages. Linguistics of the Tibeto-Burman area 15(2). 1-19.

Sun, Hongkai. 1999. On the Tibeto-Burman languages of the eastern Himalayan area in China. Linguistics of the Tibeto-Burman area 22(2). 61-72.

Swank, Heidi. 2014. Rewriting Shangri-La: Tibetan youth, migrations and literacies in McLeod Ganj, India. Leiden: Brill.

Suzuki, Hiroyuki and Sonam Wangmo. 2017. Language evolution and vitality of Lhagang Tibetan: A Tibetic language as a minority in Minyag Rabgang. International journal of the sociology of language. 
Tas, A. Rona. 1966. Tibeto-Mongolica: The Tibetan loanwords of Monguor and the development of the archaic Tibetan dialects. The Hague: Mouton.

Tenzin Jinba. 2013. In the land of the eastern queendom: The politics of gender and ethnicity on the Sino-Tibetan border. Seattle: University of Washington Press.

Theobold, Ulrich. 2013. War finance and logistics in late imperial China: A study of the second Jinchuan campaign (1771-1776). Leiden: Brill.

Thomason, Sarah Grey. 2001. Language contact: An introduction. Edinburgh: Edinburgh University Press.

Thurston, Timothy. 2012. An Introduction to Tibetan sa bstod speeches in A mdo. Asian Ethnology 71(1). 49-73.

Thurston, Timothy. 2015. Laughter on the grassland: A diachronic study of A mdo Tibetan comedy and the public intellectual in western China. The Ohio State University PhD thesis.

Todal, Jon. 1999. Minorities with a minority: Language and the school in the Sami areas of Norway. Language, culture, and curriculum 11(3). 124-136.

Tournadre, Nicolas. 2003. The dynamics of Tibetan-Chinese bilingualism: The current situation and future prospects. China perspectives 45. 1-9. http://chinaperspectives.revues.org/231

Tournadre, Nicolas. 2008. Arguments against the concept of 'conjunct' /'disjunct' in Tibetan. In Brigitte Huber, Marianne Volkart \& Paul Widmer (eds.), Chomolangma, demawend und kasbek, festschrift für Roland Bielmeier, 281-308. Halle: International Institute for Tibetan Buddhist Studies.

Tournadre, Nicolas. 2013. The Tibetic languages and their classification. In Thomas Owen-Smith \& Nathan Hill (eds.), Trans-Himalayan linguistics: Historical and descriptive linguistics of the Himalayan area. Berlin: Mouton de Gruyter.

Tournadre, Nicolas. 2015. Le development des langues et les nouvelles technologies de la communication: le miracle tibétain. http://www.senat.fr/ga/ga127/ga12715.html\#toc257

Tournadre, Nicolas \& Françoise Robin. 2006. Le grand livre des proverbes Tibétains. Montréal: Presses du Châtelet.

Tribur, Zoe. 2017. Social network structure and language change in Amdo Tibetan. International journal of the sociology of language.

Tunzhi. 2017. Language vitality and glottonyms in the Ethnic Corridor: The Rta'u language. International journal of the sociology of language.

Tsering Drolma \& Arthur Wilson 2009. Tibetan contemporary songs and music video: Focus and direction 2000-2009. Tibet journal. 34(1). 15-175.

Tsung, Linda. 2009. Minority languages, education, and communities in China. London: Palgrave Macmillan.

Tuttle, Gray. 2008. The failure of ideologies in China's relations with Tibetans. In Jacques Bertrand \& André Laliberté (eds.), Multination states in Asia: Accommodation or resistance, 219-243. Cambridge: Cambridge University Press.

Tuttle, Gray. 2012. Building up the Dge lugs pa base in A mdo: The role of Lha sa, Beijing, and local agency. Zangxue xuekan [Journal of Tibetology]. 7. 126-140.

Upton, Janet L. 2000. Notes towards a native Tibetan ethnology: An introduction to and annotated translation of dMu dge bSam gtan's essays on Dwags po (Baima Zangzu). Tibet journal 25(1). 3-26.

van Spengen, Wim. 2000. Tibetan border worlds: A geo-historical analysis of trade and traders. London: Routledge.

Voegelin, Carl F., Florence M. Voegelin \& Noel W. Schutz Jr. 1967. The language situation in Arizona as part of the southwest culture area. In Dell Hymes \& William Bittle (eds.), Studies 
in southwestern ethnolinguistics: Meaning and history in the languages of the American southwest, 403-451. The Hague: Mouton.

Warner, Cameron David. 2013. Hope and sorrow: Uncivil religion, Tibetan music videos, and YouTube. Ethnos: Journal of Anthropology 78(4). 543-568.

Weber, Eugen. 1976. Peasants into Frenchmen: The modernization of rural France 1870-1914. Stanford: Stanford University Press.

Wehrli, Eugen. 1992. The Tibetan local self-defense organizations in Amdo from 1900 to 1950. China Tibetology. Special Issue 1. 315-321.

Weiner, Benno. 2012. The Chinese revolution on the Tibetan frontier: State building, national integration, and socialist ransformation, Zeku (Tsekok) county, 1953-1958. Columbia University PhD dissertation.

Wendel, John. 2005. Notes on the ecology of language. Bunkyo gakuin university academic journal 5. 51-76.

Wendel, John \& Patrick Heinrich. 2012. A framework for language endangerment dynamics: The effects of contact and social change on language ecologies and language diversity. International journal for the sociology of language 218. 145-166.

Wildau, Gabriel. 2015. China backs up silk road ambitions with $\$ 62$ bn capital injection. Financial times, http://www.ft.com/intl/cms/s/0/0e73c028-e754-11e4-8e3f00144feab7de.html

Williams, Glynn. 2005. Sustaining language diversity in Europe: Evidence from the Euromosaic project. Basingstoke: Palgrave Macmillan.

Winkler, Daniel. 2008. Yartsa gunbu (Cordyceps sinensis) and the fungal commodification of Tibet's rural economy. Economic botany 62(3). 291-305.

Wolf, Eric. 2010. Europe and the people without history. Berkely: University of California Press.

Wright, Stuart. 2014. Standard policy or a model for inequality? School consolidation and centralised boarding schools in Amdo, Tibet. Dynamics of change: Agents, mechanisms and economics of transformation in Amdo, Conference of the Amdo Research Network, Humboldt University Berlin. 13-15 December 2014

Xinhua. 2015. Vision and actions on jointly building belt and road. http://english.qstheory.cn/ 2015-03/30/c_1114807064.htm

Yang, Yangming. 2005. For the illumination of Tibet. China Tibet magazine, http://info.tibet.cn/ en/news/tin/t20050906_53259.htm

Yangdon Dhondup. 2008. Dancing to the beat of modernity: The rise and development of Tibetan pop music. In Robert Barnett \& Robert Schwarts (eds.), Tibetan modernities: Notes from the field on cultural and social change, 285-304. Leiden: Brill.

Yeh, Emily T. 2000. Forest claims, conflicts and commodification: The political ecology of Tibetan mushroom-harvesting villages in Yunnan Province, China. The China quarterly 161. 264-278.

Yeh, Emily T. 2013a. Blazing pelts and burning passions: Nationalism, cultural politics, and spectacular decommodification in Tibet. The Journal of Asian Studies 72(2). 319-344.

Yeh, Emily T. 2013b. Taming Tibet: Landscape transformation and the gift of Chinese development. Ithaca and London: Cornell University Press.

Yeh, Emily T. \& Mark Henderson. 2008. Interpreting urbanization in Tibet: Administrative scales and discourses of modernization. Journal of the International Association of Tibetan Studies 4. 1-44. 
Yeshe, Kalsang. 2012. A preliminary note on Chinese codeswitching in modern Lhasa Tibetan. In Robert Barnett \& Ronald David Schwartz (eds.), Tibetan modernities: Notes from the field on cultural and social change, 213-248. Leiden: Brill.

Yi, Lin. 2007. Ethnicization through schooling: The mainstream discursive repertoires of ethnic minorities. The China Quarterly 192. 933-948.

Yudru Tsomu. 2015. The rise of Gönpo Namgyel in Khams: The blind warrior of Nyarong. New York: Lexington Books.

Zenz, Adrian. 2010. Beyond assimilation: The Tibetanisation of Tibetan education in Qinghai. Inner Asia 12(2). 293-315.

Zenz, Adrian. 2014. 'Tibetanness' under threat? Neo-Integrationism, minority education and career strategies in Qinghai, P.R. China. Leiden: Brill.

Zhang, Guobao. 2010. Journal notes on development of electricity infrastructure in Tibet. Qiushi Journal (English edition), http://english.qstheory.cn/magazine/201002/201109/ t20110920_111410.htm

Zhou, Maocao. 2007. The use and development of Tibetan in China. In Minglang Zhou \& Hongkai Sun (eds.), Language policy in the People's Republic of China: Theory and practice since 1949, 221-238. Boston: Kluwer Academic Publishers.

Zhou, Minglang. 2004. Minority language policy in China: Equality in theory and inequality in practice. In Minglang Zhou \& Hongkai Sun (eds.), Language policy in the People's Republic of China: Theory and practice since 1949, 71-96. Boston: Kluwer Academic Publishers.

Zhu, Zhiyong. 2007. State schooling and ethnic identity: The politics of a Tibetan neidi secondary school in China. New York: Lexington Books. 